\title{
Controlled Polymerization of Electron-deficient Naphthalene-diimide Containing Monomer by Negishi-type Catalyst-transfer Polymerization
}

\author{
Eisuke Goto $^{1,2}$, Hideharu Mori ${ }^{1}$, Mitsuru Ueda ${ }^{1}$ and Tomoya Higashihara ${ }^{1,3 *}$ \\ ${ }^{1}$ Department of Polymer Science, Engineering and Graduate School of Science and Engineering, \\ Yamagata University, 4-3-16, Jonan, Yonezawa 992-8510, Japan \\ ${ }^{2}$ Research Fellowship of Japan Society for the Promotion of Science (JSPS), \\ 5-3-1, Kojimachi, Chiyoda-ku, Tokyo, 102-0083, Japan \\ ${ }^{3}$ Japan Science and Technology Agency (JST), PRESTO, \\ 4-1-8, Honcho, Kawaguchi, Saitama 332-0012, Japan \\ thigashihara@yz.yamagata-u.ac.jp
}

\begin{abstract}
Negishi-type Catalyst-Transfer Polymerization (NCTP) of electron-deficient monomers has been attempted for the first time. Imide or ketone groups in such monomers show an excellent electron-deficient property. However, these functional groups cannot generally tolerate towad highly reactive Grignard reagents. In this work, we applied a zincate complex with lower basicity, ${ }^{t} \mathrm{Bu}_{4} \mathrm{ZnLi}_{2}$, for the polymerization of a naphthalene-diimide-containing monomer. Zinc-halogen exchange reaction was quantitatively conducted at $60{ }^{\circ} \mathrm{C}$ for $1 \mathrm{~h}$ without any protection of the imide group. Then, the polymerization was carried out by adding the Pd catalyst to afford an electron-deficient polymer, PTNDIT $\left(M_{\mathrm{n}}=8,400\right.$ and $\left.Ð=1.35\right)$.
\end{abstract}

Keywords: Catalyst-Transfer, Protection-free, Zincate complex, $\boldsymbol{n}$-type polymer.

\section{Introduction}

Polymer solar cells (PSCs) [1] and organic field-effect transistors (OFETs) [2] are attractive devices with the properties of light weight, flexible and low-cost by fabricating on the transparent films such as polyimides, polyethers and polyesters. $\pi$-Conjugated polymers (CPs) are promising candidates for the active layer of these devices because of its high hole and/or electron mobility and high solubility toward organic solvents. To synthesize CPs, the polycondensation is conducted by cross coupling reactions such as Suzuki coupling and Stille coupling reactions. However, it is difficult to control not only the molecular weight (MW) but also dispersity $(\nexists)$ of each polymer obtained in a step-growth manner, theoretically. The effect of the MW and $D$ of CPs has already been discussed by several researchers and they concluded that optimum MW [3] and low $Ð[4,5]$ of CPs strongly enhance the properties of optoelectronic devices, depending on each polymer structure and/or the morphology in the active layer film.
In the past decade, with regard to $p$-type semiconducting materials such as poly(3-hexylthiophene) (P3HT), controlled synthesis was accomplished by catalyst-transfer polymerization. Yokozawa and coworkers [6] and McCullough and coworkers [7] established a Kumada Catalyst-Transfer Polymerization (KCTP) system, independently, and controlled the MW and $\nexists$ values of regioregular P3HT. In addition, by using KCTP, a wide variety of electron-donating monomers becomes available for polymerization and a lot of block copolymers $[7 \mathrm{~b}, 8]$ and end-functional polymers [9] could easily be synthesized. However, taking into account the application of CPs to all-polymer solar cells (All-PSCs) [10], in which the active layer is binary blend of $p$-type polymer and $n$-type polymer, the general controlled polymerization method of not only electron-donating monomer but also electron-deficient monomer is absolutely necessary. However, there are only a few successful examples of controlling the polymerization of electron-deficient monomer containing electron 


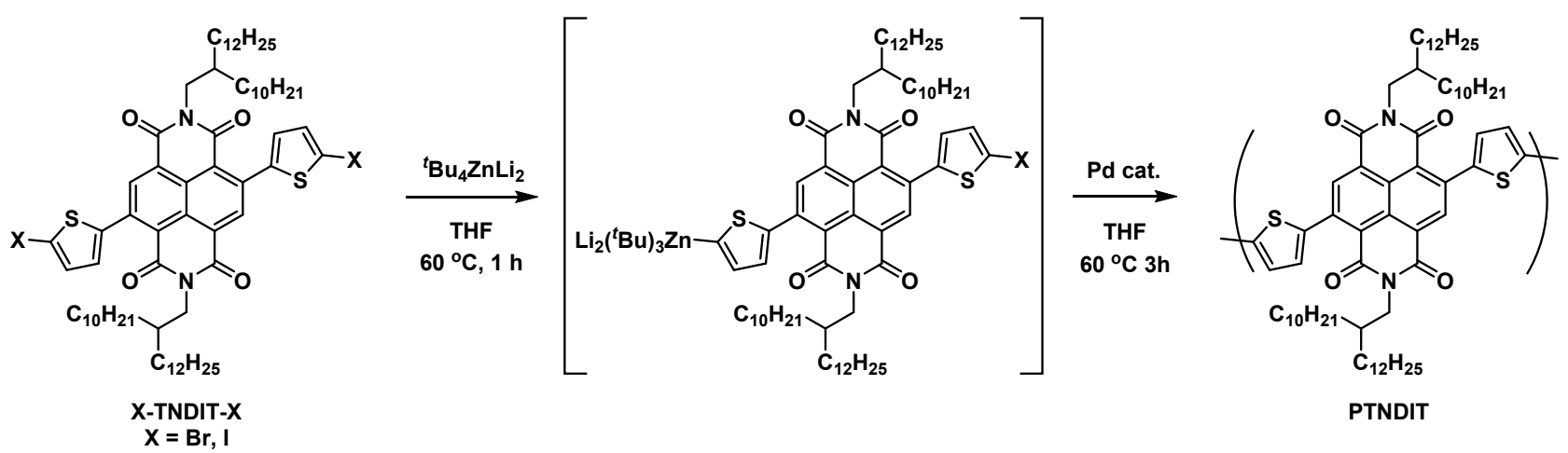

Scheme 1. Synthesis of PTNDIT by NCTP using ${ }^{t} \mathrm{Bu}_{4} \mathrm{ZnLi}_{2}$.

withdrawing groups. Poly(pyridine) [11] and poly(benzotriazole) [12] synthesized by KCTP have already been reported. However, the application of these polymers are unfortunately limited. The polymers containing naphthalene-diimide [13] or perylene-diimide [14], which show high electron mobility, were synthesized by Kiriy and coworkers by catalyst-transfer polymerization of the anion-radical monomer in the presence of the Pd or $\mathrm{Ni}$ catalyst. However, the obtained polymers possess high $D$ values even though they acheive high enough MWs of the polymers. A major issue in the polymerization of electron-deficient monomer would be their increased size and polarization. While the effective catalyst-transfer is the key factor to control the MW and $D$ values, these complicated monomer structure induces the undesirable termination or chain-transfer reaction. Moreover, one of other big problems is low tolerability of the functional groups such as carbonyl group in the monomer precursor against the Grignard reagents [15].

In 2012, we have established Negishi-type Catalyst-Transfer Polymerization (NCTP) using chemo-selective and bulky zincate complex, ${ }^{t} \mathrm{Bu}_{4} \mathrm{ZnLi}_{2}$, and succeeded in purification-free and protection-free polymerization of a thiophene monomer [16].

Furthermore, after the detailed investigation of the phosphorous ligands of the Ni catalyst, P3HTs with controlled MW and extremely low $\oslash$, as well as well-defined related block copolymers were successfully synthesized [17]. In this report, we focused on the controlled polymerization of electron-deficient naphthalene-diimide-containing monomer by extending our new NCTP system for the first time.

\section{Experimental}

2.1 Materials

Tetrahydrofuran (THF, dehydrated, stabilizer-free, 99.5\%, Wako Pure Chemical Industries Ltd.) was dried over sodium benzophenone and distilled before use under a nitrogen atmosphere. ${ }^{t} \mathrm{Bu}_{4} \mathrm{ZnLi}_{2}(0.215 \mathrm{M}$ in THF solution) was kindly donated by Tosoh Finechem Corporation, which could also be synthesized according to the previous report [18]. All other reagents were purchased from Aldrich, Japan or Tokyo Chemical Industry Co., Ltd., Wako Pure Chemical Industries, Ltd. and used as received. Dihalogenated monomer precursors (Br-TNDIT-Br and I-TNDIT-I) were synthesized by general bromination or iodination procedures with $\mathrm{N}$-bromosuccinimide [13a] or $\mathrm{N}$-iodosuccinimide, respectively.

\subsection{Measurement}

${ }^{1} \mathrm{H}$ NMR spectra were recorded on a JEOL JNM-ECX400 spectrometer at $25{ }^{\circ} \mathrm{C}$ or $40{ }^{\circ} \mathrm{C}$. Deuterated chloroform or tetrachloroethane were used as a solvent. Size exclusion chromatography (SEC) was measured on a JASCO GULLIVER 1500 equipped with a pump, an absorbance detector (UV, $\lambda=254 \mathrm{~nm}$ ), and three polystyrene gel columns, based on a conventional calibration curve using polystyrene standards. $\mathrm{CHCl}_{3}\left(40{ }^{\circ} \mathrm{C}\right)$ was used as a carrier solvent at the flow rate of 1.0 $\mathrm{mL} / \mathrm{min}$. 
Table 1. Synthetic results of PTNDIT catalysed by Pd catalysts.

\begin{tabular}{|c|c|c|c|c|c|}
\hline Run & $\mathrm{x}$ & Pd Cat. & Ligand & $M_{\mathrm{n}}^{\mathrm{a}}$ & $\theta^{a}$ \\
\hline 1 & $\mathrm{Br}$ & $\mathrm{Pd}_{2}(\mathrm{dba})_{3}$ & $\mathrm{P}(0-\text { Tolyl })_{3}$ & 7,700 & 1.45 \\
\hline 2 & $\mathrm{Br}$ & & - & 5,600 & 1.29 \\
\hline 3 & 1 & $\mathrm{Pd}_{2}(\mathrm{dba})_{3}$ & $\mathrm{P}(0-\text { Tolyl })_{3}$ & 8,400 & 1.35 \\
\hline 4 & 1 & 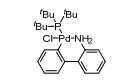 & - & 5,800 & 1.32 \\
\hline 5 & 1 & $\mathrm{Pd}_{2}(\mathrm{dba})_{3}$ & John Phos ${ }^{\mathrm{b}}$ & 5,500 & 1.19 \\
\hline 6 & 1 & $\mathrm{Pd}(\mathrm{OAc})_{2}$ & $\mathrm{P}(\mathrm{o}-\mathrm{Tolyl})_{3}$ & 5,500 & 1.24 \\
\hline \multicolumn{6}{|c|}{${ }^{\mathrm{a}} M_{\mathrm{n}}$ and $\Theta$ values of PTNDIT were determined by SEC using } \\
\hline & & dards. ${ }^{b}$ & t-butylphos & blf & \\
\hline
\end{tabular}

2.3 General procedure for Negishi-type catalyst-transfer polymerization.

The NCTP was carried out in THF at $60{ }^{\circ} \mathrm{C}$ under a nitrogen atmosphere using with $\mathrm{Pd}$ catalyst. In a typical experiment (Run 3), I-TNDIT-I (83.7 $\mathrm{mg}, 0.0618 \mathrm{mmol}$ ) and trimethoxybenzene $(5.0 \mathrm{mg}$, $0.030 \mathrm{mmol}$ ) as an internal standard were placed in a $20 \mathrm{~mL}$ two-necked flask purged with a nitrogen atmosphere. After dissolving I-TNDIT-I in THF $(15 \mathrm{~mL})$, a THF solution of ${ }^{t} \mathrm{Bu}_{4} \mathrm{ZnLi}_{2}(0.215 \mathrm{M} \mathrm{x}$ $0.07 \mathrm{~mL}=0.016 \mathrm{mmol})$ was added at room temperature and stirred at $60{ }^{\circ} \mathrm{C}$ for $1 \mathrm{~h}$ to afford a THF solution of zincate complex-type monomer. Finally, the Pd catalyst $(0.0061 \mathrm{mmol})$ solution (5 $\mathrm{mL}$ ), which was prepared in another batch by mixing $\mathrm{Pd}_{2}(\mathrm{dba})_{3}(5.6 \mathrm{mg}, 0.0061 \mathrm{mmol})$ and tri(o-tolyl)phosphine $(17.4 \mathrm{mg}, 0.057 \mathrm{mmol})$ in THF $(5 \mathrm{~mL})$, was added to start the polymerization at $60{ }^{\circ} \mathrm{C}$ and stirred for $3 \mathrm{~h}$, followed by quenching with a $5 \mathrm{M} \mathrm{HCl}$ solution $(1 \mathrm{~mL})$. The quenched solution was poured into a large amount of methanol $/ \mathrm{H}_{2} \mathrm{O}(150 \mathrm{~mL} / 75 \mathrm{~mL})$ to precipitate the polymer. After filtration, the sample was purified by soxhlet extraction with methanol, acetone and then, $\mathrm{CHCl}_{3}$. After drying under vacuum, the crude PTNDIT was obtained $\left(25.6 \mathrm{mg}, 38 \%, M_{\mathrm{n}}(\mathrm{SEC})=\right.$ $8,400, Ð=1.35) .{ }^{1} \mathrm{H} \mathrm{NMR}\left(\mathrm{C}_{2} \mathrm{D}_{2} \mathrm{Cl}_{4}\right): \delta 0.90(12 \mathrm{H})$, $1.10-1.53(80 \mathrm{H}), 2.06(2 \mathrm{H}), 4.17(4 \mathrm{H}), 7.40(4 \mathrm{H})$, $8.87 \mathrm{ppm}(2 \mathrm{H})$.

\section{Results and Discussion}

3.1 Zinc-halogen exchange reaction
First of all, Zn-X exchange reaction between $\mathrm{X}$-TNDIT-X and ${ }^{t} \mathrm{Bu}_{4} \mathrm{ZnLi}_{2}$ were conducted in THF at $60{ }^{\circ} \mathrm{C}$ for $1 \mathrm{~h}$ as shown in Scheme 1. After the quenching with $\mathrm{HCl}, \mathrm{H}-\mathrm{TNDIT}-\mathrm{X}$ were quantitatively obtained (Figure 1), which indicates that $\mathrm{Zn}-\mathrm{X}$ exchange reaction was successfully proceeded without any decomposition or side reactions of imide groups in the monomer.
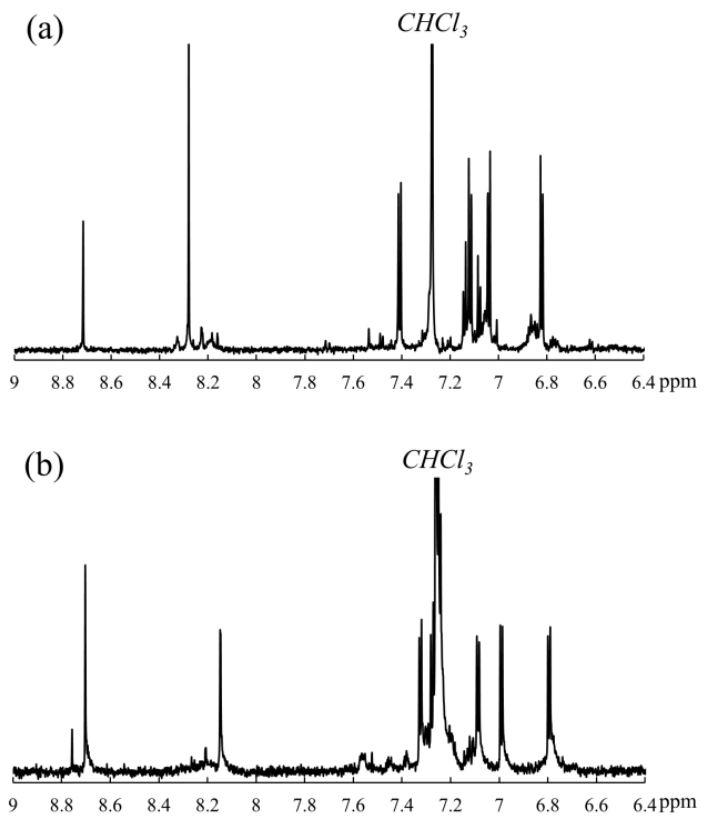

Figure 1. ${ }^{1} \mathrm{H}$ NMR spectra of (a) H-TNDIT-Br and (b) H-TNDIT-I.

\subsection{Polymerization}

The polymerization of the monomer was carried out at $60{ }^{\circ} \mathrm{C}$ for $3 \mathrm{~h}$ and the results, targeting the same MW $\left(M_{\mathrm{n}}=10,000\right)$, were summarized in Table 1.

First, we tried to start polymerization of $\mathrm{Br}-\mathrm{TNDIT}-\mathrm{Br}$ by $\mathrm{Ni}$ (dppe) $\mathrm{Cl}_{2}$ which gives good results in previous report by Kiriy and coworker [13a,b]. However, only the oligomer or monomer were obtained in our NCTP system. On the other hand, $\mathrm{Pd}_{2}(\mathrm{dba})_{3}$ and $\mathrm{P}(o \text {-Tolyl })_{3}$ which are commonly used in stille coupling or Suzuki coupling afforded a PTNDIT with relatively high MW and moderate $Ð\left(M_{\mathrm{n}}=7,700, \oslash=1.45\right)$ (Run 1). Kiriy and coworker also reported that $\mathrm{Pd}$ catalyst with electron-rich and bulky ligand such as $\mathrm{P}^{t} \mathrm{Bu}_{3}$ accomplished strong interaction and effective intramolecular catalyst-transfer [13c]. 
Therefore, chloro[(tri-tert-butylphosphine)-2(2-aminobiphenyl)] palladium(II) $\left(\mathrm{P}\left({ }^{t} \mathrm{Bu}\right)_{3} \quad \mathrm{Pd}\right.$ G2) was then adopted and resulted in lower $\oslash$ which indicates that strong interaction has been generated in catalyst-transfer, however, leading to lower MW unfortunately, as compared to Run 1 (Run 2). We speculate that the steric hindrance of both reactive sites of the monomer and $\mathrm{P}^{t} \mathrm{Bu}_{3}$ with $\mathrm{Pd}$ catalyst prevents an effective transmetalation in the cross coupling cycle. Next, we tried to polymerize I-TNDIT-I with several Pd catalysts and almost the same tendency as Br-TNDIT-Br was observed. In Run 3, the highest MW was achieved $\left(M_{\mathrm{n}}=8,400\right.$, $Ð=1.35)$ using $\mathrm{Pd}_{2}(\mathrm{dba})_{3}$ and $\mathrm{P}(o \text {-Tolyl })_{3}$. SEC UV trace clearly shows the existence of the polymeric product (Figure 2). From ${ }^{1} \mathrm{H}$ NMR spectroscopy (Figure 3 ), the product was clearly identified and all the signals could be assigned, indicating the absence of decomposition or side reactions of reactive imide groups in the monomer.

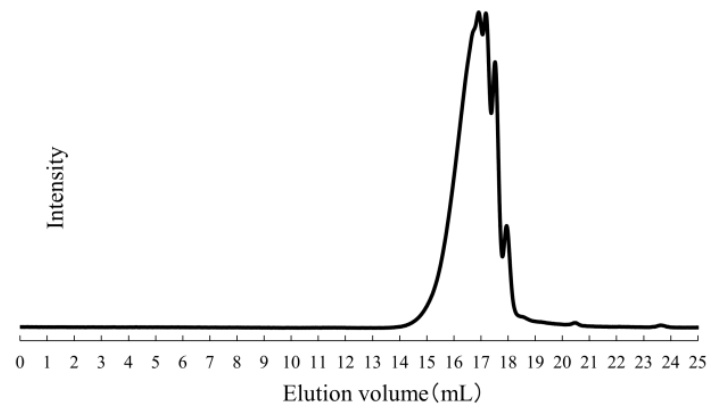

Figure 2. SEC UV trace of PTNDIT (Run 3)

(eluent: $\mathrm{CHCl}_{3}$ )

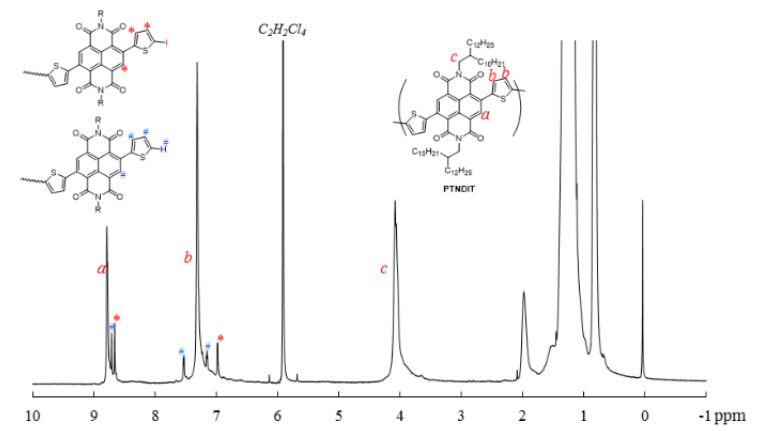

Figure 3. ${ }^{1} \mathrm{H}$ NMR spectrum of PTNDIT (Run 3) (solvent: $\mathrm{C}_{2} \mathrm{D}_{2} \mathrm{Cl}_{4}$ )

However, MW was decreased when $\mathrm{Pd}$ catalyst with bulky ligands were adopted (Run 4 and Run 5) even though PTNDIT with lower $D$ was obtained. In the case of using $\mathrm{Pd}(\mathrm{OAc})_{2}$ as another Pd catalyst, lower MW compared with Run 3 and low $\oslash$ were observed (Run 6).

\section{Conclusion}

In conclusion, we have newly performed the NCTP of electron-deficient naphthalene-diimide containing monomer to synthesize the typical $n$-type polymer. When the mixed solution of $\mathrm{Pd}_{2}(\mathrm{dba})_{3}$ and $\mathrm{P}(o \text {-Tolyl })_{3}$ was adopted for polymerization, the highest MW $\left(M_{\mathrm{n}}=8,400\right)$ was accomplished with relatively low $Ð$ (1.35).

\section{Acknowledgement}

The authors thank the Japan Society for the Promotion of Science for the partial financial support by KAKENHI (\#24655097). They also thank Tosoh Finechem Corp. for the donation of ${ }^{t} \mathrm{Bu}_{4} \mathrm{ZnLi}_{2}$. E. Goto thanks Research Fellowship of Japan Society for the Promotion of Science for Young Scientist and Innovative Flex Course for Frontier Organic Material Systems (iFront) at Yamagata University for financial support. The financial support of this work from Japan Science and Technology Agency (JST), PRESTO program (\#JY220176) is highly appreciated.

\section{References}

1. (a) C. J. Brabec, S. Gowrisanker, J. J. M. Halls, D. Laird, S. Jia, S. P. Williams, $A d v$. Mater. 22 (2010) 3839-3856. (b) B. C. Thompson, J. M. J. Fréchet, Angew. Chem. Int. Ed. 47 (2008) 58-77.

2. (a) S. Allard, M. Forster, B. Souharce, H. Thiem, U. Scherf, Angew. Chem. Int. Ed. 47 (2008) 4070-4098. (b) A. Facchetti, Chem. Mater. 23 (2011) 733-758. (c) Y. Guo, G. Yu, Y. Liu, Adv. Mater. 22 (2010) 4427-4447. (d) S. Liu, W. M. Wang, A. L. Briseno, S. C. B. Mannsfeld, Z. Bao, Adv. Mater. 21 (2009) 1217-1232.

3. (a) R. J. Kline, M. D. McGehee, E. N. Nadnikova, J. Liu, J. M. J. Fréchet, $A d v$. Mater., 15 (2003) 1519-1522. (b) L. Meager, R. S. Ashraf, C. B. Nielsen, J. E. Donaghey, Z. Huang, H. Bronstein, J. R. Durrant, L. McCulloch, J. Mater. Chem. C, 2 (2014) 8593-8598. 
4. S. Himmelberger, K. Vandewal, Z Fei, M Heeney, A Salleo, Macromolecules 47 (2014) 7151-7157.

5. L. Lu, T. Zheng, T. Xu, D. Zhao, L. Yu, Chem. Mater. 27 (2015) 537-543.

6. (a) A. Yokoyama, R. Miyakoshi, T. Yokozawa, Macromolecules 37 (2004) 1169-1171. (b) R. Miyakoshi, A. Yokoyama, T. Yokozawa, J. Am. Chem. Soc. 127 (2005) 17542-17547.

7. (a) E. E. Sheina, J. Liu, M. C. Iovu, D. W. Laird, R. D. McCullough, Macromolecules 37 (2004) 3526-3528. (b) M. C. Iovu, E. E. Sheina, R. R. Gil, R. D. McCullough, Macromolecules 38 (2005) 8649-8656.

8. (a) T. Yokozawa, I. Adachi, R. Miyakoshi, A. Yokoyama, High Perform. Polym. 19 (2007) 684-699. (b) K. Ohshimizu, M. Ueda, Macromolecules 41 (2008) 5289-5294. (c) Y. Zhang, K. Tajima, K. Hirota, K. Hashimoto, $J$. Am. Chem. Soc. 130 (2008) 7812-7813. (d) Y.C. Lai, K. Ohshimizu, A. Takahashi, J. C. Hsu, T. Higashihara, M. Ueda, W. C. Chen, J. Polym. Sci. Part A: Polym. Chem. 49 (2011) 2577-2587. (e) A. Takahashi, C. J. Lin, K. Ohshimizu, T. Higashihara, W. C. Chen, M. Ueda, Polym. Chem. 3 (2012) 479-485. (f) Z. Wu, R. J. Ono, Z. Chen, C. W. Bielawski, J. Am. Chem. Soc. 132 (2010) 10184-10194. (g) H. Fujita, T. Michinobu, M. Tokita, M. Ueda, T. Higashihara, Macromolecules 45 (2012) 9643-9656.

9. (a) M. Jeffries-EL, G. Sauvé, R. D. McCullough, Adv. Mater. $16 \quad$ (2004) 1017-1019. (b) M. Jeffries-EL, G. Sauvé, R. D. McCullough, Macromolecules 38 (2005) 10346-10352.

10. (a) C. Lee, H. Kang, W. Lee, T. Kim, K.-H. Kim, H. Y. Woo, C. Wang, B. J. Kim, $A d v$. Mater. 10.1002/adma.201405226. (b) T. Earmme, Y.-J. Hwang, N. M. Murari, S. Subramaniyan, S. A. Jenekhe, J. Am. Chem. Soc. 135 (2013) 14960-14963 (c) Y. Zhou, T.
Kurosawa, W. Ma, Y. Guo, L. Fang, K. Vandewal, Y. Diao, C. Wang, Q. Yan, J. Reinspach, J. Mei, A. L. Appleton, G. I. Koleilat, Y. Gao, S. C. B. Mannsfeld, A. Salleo, H. Ade, D. Zhao, Z. Bao, Adv. Mater. 26 (2014) 3767-3772. (d) T. Earmme, Y.-J. Hwang, S. Subramaniyan, S. A. Jenekhe, $A d v$. Mater. 26 (2014) 6080-6085.

11. Y. Nakashima, A. Yokoyama, T. Yokozawa, Journal of Polymer Science Part A: Polymer Chemistry, 50 (2012) 1054-1061.

12. (a) C. R. Bridges, T. M. McCormick, G. L. Gibson, J. Hollinger, D. S. Seferos, J. Am. Chem. Soc. 135 (2013) 13212-13219. (b) C. R. Bridges, H. Yan, A. A. Pollit, D. S. Seferos, ACS Macro Lett. 3 (2014) 671-674.

13. (a) V. Senkovskyy, R. Tkachov, H. Komber, M. Sommer, M. Heuken, B. Voit, W. T. S. Huck, V. Kataev, A. Petr, A. Kiriy, J. Am. Chem. Soc. 133 (2011) 19966-19970. (b) V. Senkovskyy, R. Tkachov, H. Komber, A. John, J.-U. Sommer, A. Kiriy, Macromolecules 45 (2012) 7770-7777. (c) R. Tkachov, Y. Karpov, V. Senkovskyy, I. Raguzin, J. Zessin, A. Lederer, M. Stamm, B. Voit, T. Beryozkina, V. Bakulev, W. Zhao, A. Facchetti, A. Kiriy, Macromolecules 47 (2014) 3845-3851.

14. W. Liu, R. Tkachov, H. Komber, V. Senkovskyy, M. Schubert, Z. Wei, A. Facchetti, D. Neher, A. Kiriy, Polym. Chem. 5 (2014) 3404-3411.

15. T Yokozawa, Y Nanashima, Y Ohta, ACS Macro Lett. 1 (2012) 862-866.

16. T. Higashihara, E. Goto, M. Ueda, ACS Macro Lett. 1 (2012) 167-170.

17. E. Goto, S. Nakamura, S. Kawauchi, H. Mori, M. Ueda, T. Higashihara, Journal of Polymer Science Part A: Polymer Chemistry, 52 (2014) 2287-2296.

18. M. Uchiyama, T. Furuyama, M. Kobayashi, Y. Matsumoto, K. Tanaka, J. Am. Chem. Soc. 128 (2006) 8404-8405. 